\title{
Potential application of high voltage electrical discharge plasma control of Brettanomyces bruxellensis in wine
}

\begin{abstract}
The aim of this work was to investigate the effect of high voltage electrical discharge (HVED) plasma on inactivation of Brettanomyces bruxellensis yeast in red wine. Research was conducted in two phases. Firstly, the efficacy of two main plasma parameters was examined - frequency $(60,90$ and $120 \mathrm{~Hz})$ and treatment duration (3, 5, 10, 20 and $30 \mathrm{~min})$. Second phase included monitoring long-term effect of HVED plasma using optimal frequency during selected treatment durations, where culturability of B. bruxellensis was determined after 30, 60 and 90 days of storage. Results show that frequency of $120 \mathrm{~Hz}$ caused slightly higher inactivation than the lower ones. Furthermore, longer treatment durations resulted in significantly higher inactivation, wherein the treatment of 30 min showed the best results. Finally, during storage period, the inactivation effect of HVED plasma was reversed and B. bruxellensis yeast recovered almost completely in treated wine.

Keyword: Brettanomyces bruxellensis, HVED plasma, culturability, red wine
\end{abstract}

\section{Introduction}

Brettanomyces bruxellensis is often considered as the most important yeast contaminant in wines (Agnolucci et al., 2017; Oelofse et al., 2008), due to the negative impacts on wine organoleptic characteristics. Herein, main sensory changes are related with production of volatile phenols, primarily 4-ethylphenol and 4-ethylguaiacol, compounds responsible for animal, horse sweat, medicinal and animal leather odors (Chatonnet et al., 1992). This yeast causes significant financial losses in all geographic regions of the world, since contaminated wine is not desirable for consumption (Agnolucci et al., 2017; Di Toro et al., 2015). Generally, one of the main challenges of modern winemaking is controlling growth of $B$. bruxellensis, since this yeast has an ability to tolerate environmental stresses such as high ethanol content, low $\mathrm{pH}$ and oxygen, low sugar and low fermentable nitrogen concentrations (Curtin et al., 2015). Previous investigations reported that successful control of its growth could be achieved by addition of sulfur dioxide $\left(\mathrm{SO}_{2}\right)$, but suggested concentrations are relatively high - over $2.1 \mathrm{mg} / \mathrm{L}$ of molecular $\mathrm{SO}_{2}$ (Agnolucci et al., 2014), meaning that this addition will most probably result in exceeding the legal limitation regarding its dosage, as well as affect sensory properties and potentially human health. Even if the sensory and health aspect are ignored, higher addition of $\mathrm{SO}_{2}$ will not be effective in all cases due to presence of resistant strains of $B$. bruxellensis yeast and cross contaminations in cellar operations (Fabrizio et al., 2015). Moreover, it was demonstrated that addition of sulfites causes B. bruxellensis yeast to enter 'viable but not culturable' (VBNC) state, where it maintains metabolic and cellular activity but does not grow on selective media (Agnolucci i sur., 2010; Agnolucci i sur., 2017; Du Toit i sur., 2005; Serpaggi i sur., 2012).

In last several years, there has been a growing interest to find an adequate alternative for

Dr. sc. Marina Tomašević, dr. sc. Tomislava Vukušić, dr. sc. Natka Curko, Katarina Lukić, mag. ing., dr. sc. Karin Kovačevićć Ganić, University of Zagreb Faculty of Food Technology and Biotechnology, Pierottijeva 6, 10000 Zagreb, Croatia dr. sc. Stela Križanović, Ruđer Bošković Institute, Bijenička cesta 54, 10000, Zagreb, Croatia Autor za korespondenciju: mtomasevic1@pbf.hr 
$\mathrm{SO}_{2}$, where non-thermal technologies have often been emphasized. One of them is high voltage electrical discharge (HVED) plasma. Generally, plasma is referred to as the fourth state of matter and it is defined as partially or wholly ionized state of gas and discovered plasma oscillations in ionized gas (Langmuir, 1928). Due to diversity of plasma, it is used in various fields like textile, electronics, life sciences, packaging, etc. (Roth et al., 2007). In the past several years, application of HVED plasma in food technology, especially for microbial inactivation, has been often highlighted (Scholtz et al., 2015; Vukušić et al., 2016). Generally, its efficiency in controlling of undesired microorganisms depends on numerous factors, such as type of microorganism, applied treatment parameters (voltage, frequency, power, discharge polarity, reactor configuration) and physicochemical parameters of treated media $(\mathrm{pH}$, conductivity, temperature, generated radicals) (Liao et al., 2017; Misra et al., 2011; Stulić et al., 2019; Vukušić et al., 2016). Recent investigation showed that HVED plasma can be successfully employed for microbial destruction on fresh products, such as strawberries, milk, lettuce and potatoes and increasing their shelf life (Fernandez et al., 2013; Gurol et al., 2012; Misra et al., 2014).

The aim of this research was to investigate the effect of HVED process parameters (frequency and treatment duration) on inactivation of B. bruxellensis in red wine. Also, long-term effect of HVED plasma using optimal frequency and selected treatment durations, during 90 days of storage, was examined.

\section{Materials and methods}

Chemicals

Deionized water was produced by a Millipore Milli Q system (Bedford, USA). Brettanomyces bruxellensis CBS 2499 was purchased from Westerdijk Fungal Biodiversity Institute (Utrecht, Netherlands) and commercial Brettanomyces agar from Laboratorios Conda (Madrid, Spain). Sodium chloride, p.a. was obtained from Gram-mol (Zagreb, Croatia).

\section{Wines}

Wine used in this research was young red wine Cabernet Sauvignon (Vitis vinifera L.), vintage 2016, obtained from winery Erdutski vinogradi (Erdut, Croatia). Prior to treatments, wine was inoculated with Brettanomyces bruxellensis yeast at approximately $6 \log \mathrm{CFU} / \mathrm{mL}$. Initial cell concentration was confirmed by plate counts. Inoculation was performed $24 \mathrm{~h}$ before the treatments. Bottles were incubated at $20^{\circ} \mathrm{C} \pm 2{ }^{\circ} \mathrm{C}$ and shaken prior to sampling. In order to avoid the yeast effect, a non-treated wine with inoculated yeast was used as a control sample.

\section{High voltage electrical discharge (HVED) plasma treatments}

The plasma treatments were conducted in a $1000 \mathrm{~mL}$ glass vessel with a point to point electrode configuration in a so-called hybrid reactor with discharges in and above the liquid. The plasma was generated by high-voltage pulsed power supply (Spellman, UK), by charging a load capacitor of $1.13 \mathrm{nF}$ to up to $30 \mathrm{kV}$ and then discharging the stored charge into the plasma reactor via a rotating spark gap. Construction of the plasma reactor was schematically presented by Lukić et al. (2019). Voltage in the plasma reactor was measured and recorded using a Tektronix P6015A high voltage probe connected to a Hantek DS05202BM oscilloscope. Experiments were performed at positive polarity with argon (purity $99.99 \%$; Messer Croatia, Zagreb, Croatia) bubbled trough stainless steel needle (Microlance TM $3.81 \mathrm{~cm}$ ) at gas flow of $4 \mathrm{~L} / \mathrm{min}$. The experiment was divided in two main steps. First, an optimum frequency was determined, from three different frequencies $(60,90$ and $120 \mathrm{~Hz}$ ), applying the treatment for 3,5 and 10 
min. Next step included treatment duration examination, where the selected frequency (120 $\mathrm{Hz}$ ) was applied on wine samples during 3, 5, 10, 20 and 30 min. Generally, sample treatments were performed as follows: $300 \mathrm{~mL}$ of wine was treated with plasma using the combination of previously stated processing parameters. Temperature of the samples before and after the plasma treatment was monitored using an InfraRed Thermometer PCE-777 (PCE Instruments, Germany). Before treatment, all samples were at the room temperatures of $21 \pm 1^{\circ} \mathrm{C}$, while after the plasma exposure temperature raised for up to $1^{\circ} \mathrm{C}$ after $3 \mathrm{~min}$; up to $3^{\circ} \mathrm{C}$ after $5 \mathrm{~min}$; up to $6^{\circ} \mathrm{C}$ after $10 \mathrm{~min}$; up to $11^{\circ} \mathrm{C}$ after $20 \mathrm{~min}$ and up to $15^{\circ} \mathrm{C}$ after $30 \mathrm{~min}$ of HVED treatment. All the treatments were carried out in triplicate.

Determination of culturability of Brettanomyces bruxellensis yeast

Before and after the HVED treatments, as well as after storage period (30,60 and 90 days) the colony forming units (CFU) of $B$. bruxellensis were determined in wine samples. Commercial Brettanomyces agar plates with $100 \mathrm{mg} / \mathrm{L}$ chloramphenicol, $10 \mathrm{mg} / \mathrm{L}$ cycloheximide and 100 $\mathrm{mg} / \mathrm{L}$ coumaric acid were used, while serial dilutions were carried out using sterile saline solution. Volume of $0.1 \mathrm{~mL}$ was plated out in triplicate and incubated for $7-10$ days at $24{ }^{\circ} \mathrm{C}$. The number of colony forming units (CFU) was calculated according to the following formula:

$$
C F U=\frac{\text { number of formed colonies }}{\text { sample volume used }} \times \text { reciprocial value of decimal dilution }
$$

\section{Statistical analysis}

Statistical data analysis was carried out using Statistica V.10 software (Statsoft Inc., Tulsa, USA). Analysis of Variance (ANOVA) was performed on all independent variables of analyzed aroma compounds. In order to compare variable means and to examine which wines were different, Tukey's HSD test was used as a comparison test when samples were significantly different after ANOVA ( $p<0.05)$.

\section{Results and discussion}

The experiment, proposed in this research, was conducted in three phases. First phase consisted in variation of applied treatment frequencies during shorter treatment durations. Frequencies of 60,90 and $120 \mathrm{~Hz}$ were used for treatment during 3, 5 and $10 \mathrm{~min}$ in order to select the optimum frequency for the reduction of $B$. bruxellensis. The results are shown in Fig. 1. It can be observed that all applied treatment variations resulted in decrease of culturability, but the largest reduction was obtained by frequency of $120 \mathrm{~Hz}$, and after the longest treatment duration of $10 \mathrm{~min}$. Frequencies of 60 and $90 \mathrm{~Hz}$ showed similar results, especially after $10 \mathrm{~min}$ treatment.

Generally, the efficiency of HVED plasma treatment depends on various factors such as type of microorganism, processing variables (voltage, frequency, discharge polarity, treatment duration, gas type and exposure mode) as well as physicochemical parameters of treated solution ( $\mathrm{pH}$, conductivity, temperature, generated free radicals) (Liao et al., 2017; Misra et al., 2011; Vukušić et al., 2016). Regarding the input power, it was previously demonstrated that higher frequency and input voltage results in greater inactivation (Dasan et al., 2016; Lu et al., 2014), which is in accordance with the results obtained in this study. Moreover, Stulić et al. (2019) showed that configuration of plasma reactor is more important factor than applied frequency, wherein liquid plasma discharge showed to be more efficient than gas plasma. 


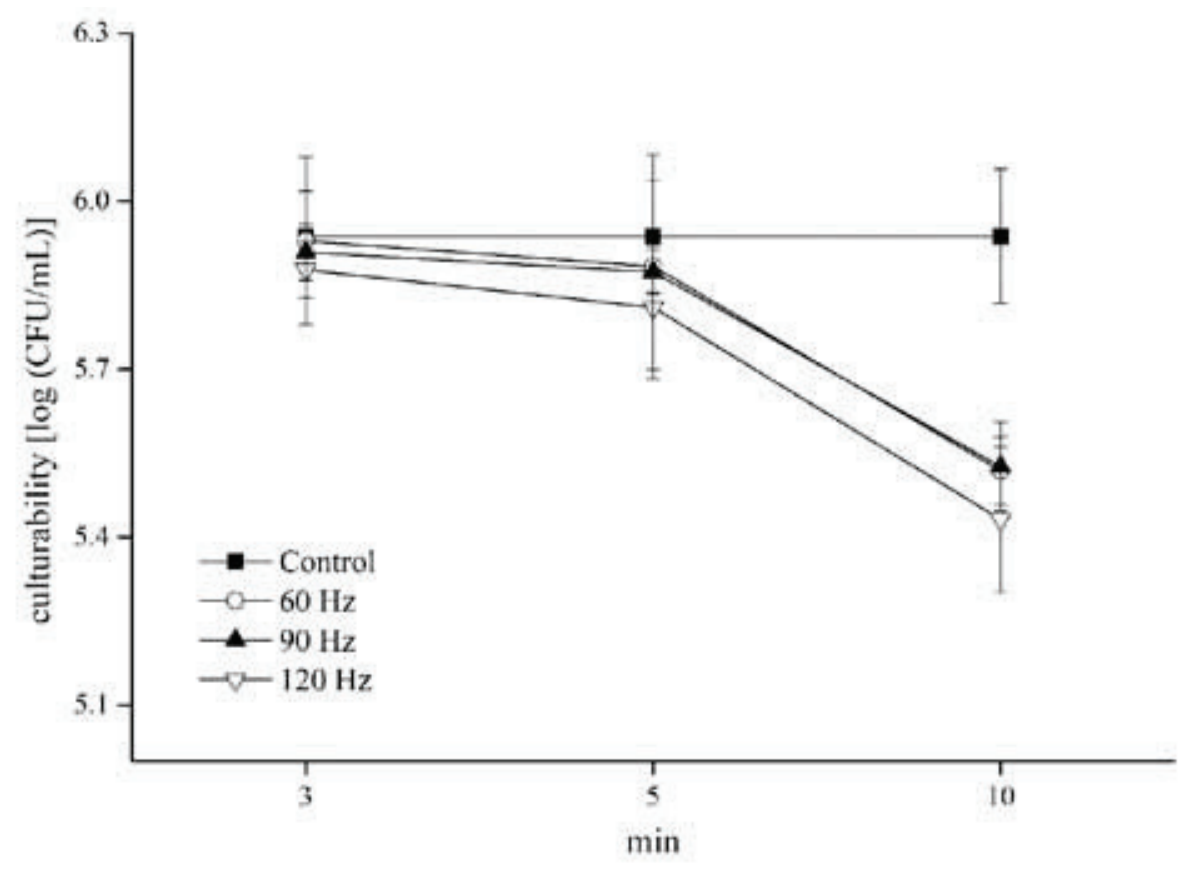

Fig. 1. Effect of frequency variations on culturability of $B$. bruxellensis yeast in red wine during 3, 5 and 10 min of HVED plasma treatment. Data presented as average value of three repetitions $(\mathrm{N}=3) \pm$ standard deviation

Slika 1. Utjecaj frekvencije na rast stanica kvasca B. bruxellensis u crnom vinu nakon 3, 5 i 10 min tretiranja hladnom plazmom. Rezultati su prikazani kao srednja vrijednost tri paralele $(\mathrm{N}=3) \pm$ standardna devijacija.

Although the best results were achieved by frequency of $120 \mathrm{~Hz}$, obtained reduction was not satisfactory, since culturability was reduced only by $10 \%$ in comparison to control sample. Besides process parameters, species of treated microorganisms plays a significant role in efficiency of applied HVED plasma treatments. For example, resistance of fungi is commonly higher than that of bacteria due to fact that the cell wall of fungi is consisted of chitin, more rigid than peptidoglycan of bacteria cell walls (Liang et al., 2012). Lower reduction, hence, could be due to higher resistance of $B$. bruxellensis cell walls. For that reason, the next phase of experiment was conducted in order to determine adequate treatment duration for maximum reduction of B. bruxellensis yeast. During this phase, five different treatment durations were examined $(3,5$, 10, 20 and $30 \mathrm{~min}$ ) with frequency fixed at $120 \mathrm{~Hz}$. Results are presented in Fig. 2, and expected trends could be observed: the longer treatment duration applied, the higher reduction of $B$. bruxellensis achieved. But, similar to the previously described results in the first phase, complete inactivation was not achieved, since the culturability was confirmed after all treatment variations. The highest reduction could be observed after 30 min-treatment that resulted in only $30 \%$ reduction in comparison to the control sample. 


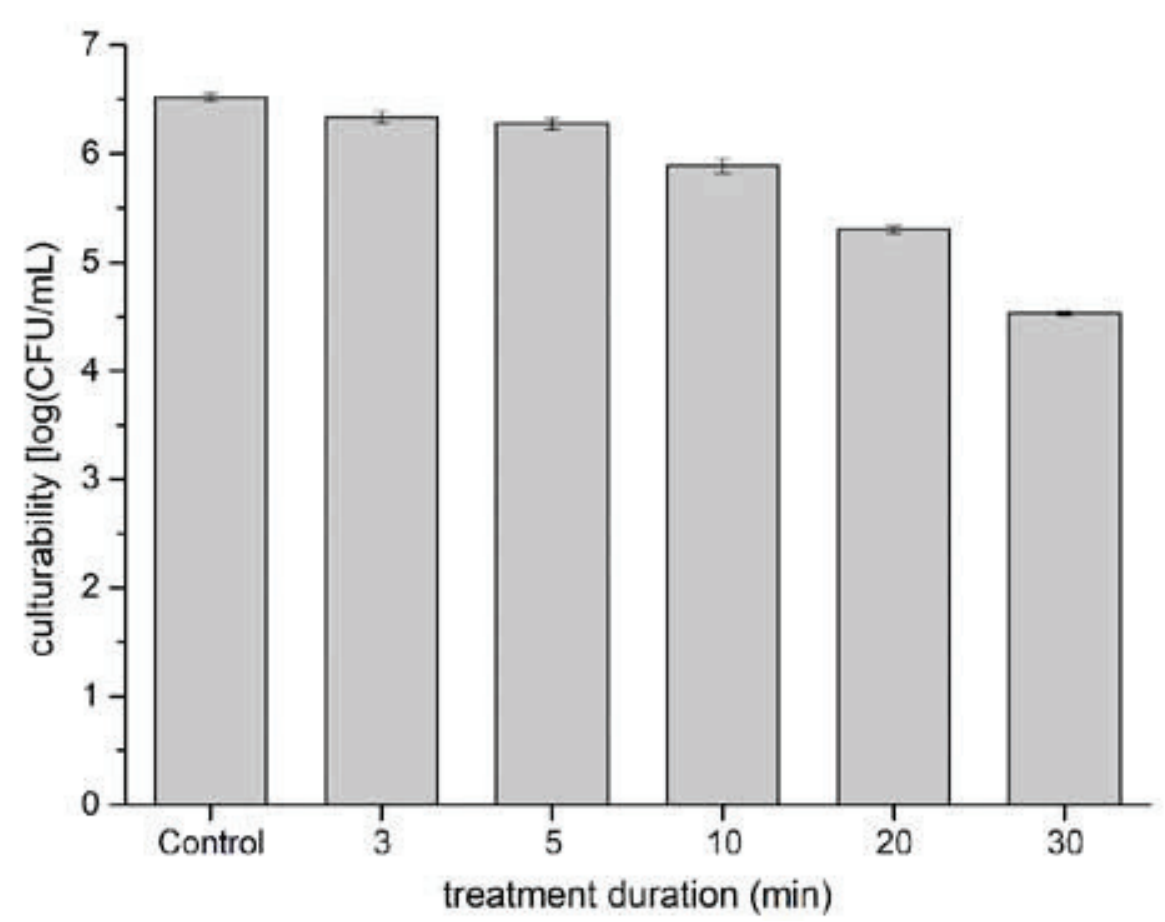

Fig. 2. Effect of treatment duration on culturability of $B$. bruxellensis yeast in red wine. Data presented as average value of three repetitions $(\mathrm{N}=3) \pm$ standard deviation

Slika 2. Utjecaj duljine tretiranja na rast stanica kvasca B. bruxellensis u crnom vinu. Rezultati su prikazani kao srednja vrijednost tri paralele $(\mathrm{N}=3) \pm$ standardna devijacija.

Finally, the third phase examined the long-term effect of applied process parameters (frequency of $120 \mathrm{~Hz}$ during 3, 5, 10, 20 and 30 min of treatment duration) on culturability of B. bruxellensis. The culturability was determined after 30,60 and 90 days of storage at room temperature and obtained results are shown in Fig. 3. As it can be seen, the yeast culturability was recovered after only 30 days of storage and there were no differences between samples treated during 5, 10, 20 and $30 \mathrm{~min}$. These samples were only different from control sample, and sample treated for $3 \mathrm{~min}$.

The results suggest that, after HVED plasma treatment, $B$. bruxellensis entered 'viable but not culturable' (VBNC) state, which is characterized by an inability of cells to divide on selective media, even though they are still alive and maintain metabolic and cellular activity (Agnolucci et al., 2010; Du Toit et al., 2005). In other words, after entering this state B. bruxellensis is undetectable and wine contamination cannot be confirmed. Generally, this state is a response of yeast to stress conditions. Recent studies showed that sulfur dioxide addition is the most important agent that induces VBNC state in B. bruxellensis (Agnolucci et al., 2010; Agnolucci et al., 2017; Du Toit et al., 2005; Serpaggi et al., 2012). As additional confirmation of VBNC state, it was demonstrated that when the stress is removed (e.g. increasing the $\mathrm{pH}$ and therefore removing the sulfur dioxide from wine), the culturability of $B$. bruxellensis completely recovered after a certain period (Serpaggi et al., 2012). This is exactly what happened in our investigation: plasma treatment induced VBNC state, but after a certain period of time cells recovered, when the stress was removed. Fig. 3 shows that after 60 days of storage there were no statistical diffe- 
rences between treated and untreated samples, while after 90 days of storage slightly lower culturability was determined in samples treated during $30 \mathrm{~min}$.

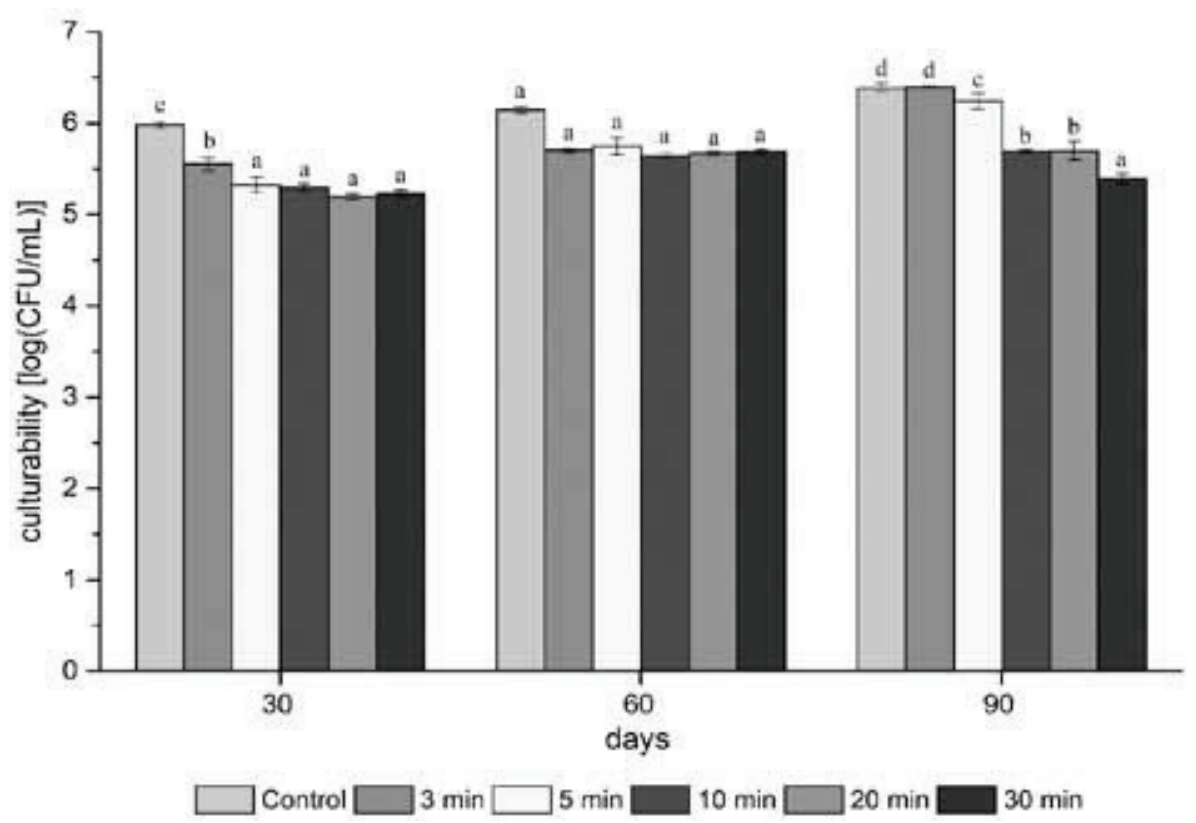

Fig. 3. Long-term effect of HVED plasma treatment (frequency of $120 \mathrm{~Hz}$ during 3, 5, 10, 20 and $30 \mathrm{~min}$ ) on culturability of B. bruxellensis yeast in red wine. Data presented as average value of three repetitions $(\mathrm{N}=3) \pm$ standard deviation. Different letters indicate significant differences among wines (Tukey's test, $\mathrm{p}<0.05$ )

Slika 3. Dugoročni utjecaj tretmana hladnom plazmom (frekvencija od $120 \mathrm{~Hz}$ tijekom 3 , $5,10,20$ i 30 min) na rast satnica kvasca B. bruxellensis u crnom vinu. Rezultati su prikazani kao srednja vrijednost tri paralele $(\mathrm{N}=3) \pm$ standardna devijacija. Različita slova označavaju statističku razliku između analiziranih vina (Tukey's test, $\mathrm{p}<0,05$ )

\section{Conclusion}

Based on the obtained results, it can be concluded that higher frequency as well as longer treatment duration resulted in higher reduction in culturability of treated yeast. Nevertheless, applied HVED plasma treatment did not result in complete inactivation of Brettanomyces bruxellensis yeast. Maximum achieved reduction in culturability was around $30 \%$. Moreover, during storage period culturability almost completely recovered, especially after 30 days of storage. It can be concluded that applied HVED treatment caused the cells to enter VBNC state, and this research represents the first evidence of VBNC state of $B$. bruxellensis after application of HVED treatment. Finally, it is necessary to conduct further research to find the most appropriate plasma configuration and process parameters combination that will result in complete inactivation of this spoilage yeast.

Acknowledgement

This work was founded by Croatian Science Foundation project 'New enological tools for the reduction of sulfur dioxide and production of high-quality wine' IP-09-2014-3796. 


\section{Literature}

Agnolucci, M., Cristani, C., Maggini, S., Rea, F., Cossu, A., Tirelli, A., Nuti, M. (2014) Impact of sulphur dioxide on the viability, culturability, and volatile phenol production of Dekkera bruxellensis in wine. Annals of Microbiology, 64, 653659.

Agnolucci, M., Rea, F., Sbrana, C., Cristani, C., Fracassetti, D., Tirelli, A., Nuti, M. (2010) Sulphur dioxide affects culturability and volatile phenol production by Brettanomyces/Dekkera bruxellensis. International Journal of Food Microbiology, 143, 76-80. DOI: 10.1016/j.ijfoodmicro.2010.07.022.

Agnolucci, M., Tirelli, A., Cocolin, L., Toffanin, A. (2017) Brettanomyces bruxellensis yeasts: impact on wine and winemaking. World Journal of Microbiology and Biotechnology, 33, 180. DOI: 10.1007/s11274-017-2345-z.

Chatonnet, P., Dubourdie, D., Boidron, J. N., Pons, M. (1992) The origin of ethylphenols in wines. Journal of the Science of Food and Agriculture, 60, 165-178. DOI: 10.1002/jsfa.2740600205.

Curtin, C., Varela, C., Borneman, A. (2015) Harnessing improved understanding of Brettanomyces bruxellensis biology to mitigate the risk of wine spoilage. Australian Journal of Grape and Wine Research, 21, 680-692. DOI: 10.1111/ ajgw.12200.

Dasan, B. G., Mutlu, M., Boyaci, I. H. (2016) Decontamination of Aspergillus flavus and Aspergillus parasiticus spores on hazelnuts via atmospheric pressure fluidized bed plasma reactor. International Journal of Food Microbiology, 216, 50-59. DOI: 10.1016/j.ijfoodmicro.2015.09.006.

Di Toro, M. R., Capozzi, V., Beneduce, L., Alexandre, H., Tristezza, M., Durante, M., Tufariello, M., Grieco, F., Spano, G. (2015) Intraspecific biodiversity and 'spoilage potential'of Brettanomyces bruxellensis in Apulian wines. LWT- Food Science and Technology, 60, 102-108. DOI: 10.1016/j.Iwt.2014.06.059.

Du Toit, W., Pretorius, I., Lonvaud-Funel, A. (2005) The effect of sulphur dioxide and oxygen on the viability and culturability of a strain of Acetobacter pasteurianus and a strain of Brettanomyces bruxellensis isolated from wine. Journal of Applied Microbiology, 98, 862-871. DOI: 10.1111/j.1365-2672.2004.02549.x.

Fabrizio, V., Vigentini, I., Parisi, N., Picozzi, C., Compagno, C., Foschino, R. (2015) Heat inactivation of wine spoilage yeast Dekkera bruxellensis by hot water treatment. Letters in Applied Microbiology, 61, 186-91. DOI: 10.1111/lam.12444. Fernandez, A., Noriega, E., Thompson, A. (2013) Inactivation of Salmonella enterica serovar Typhimurium on fresh produce by cold atmospheric gas plasma technology. Food Microbiology, 33, 24-29. DOI: 10.1016/j.fm.2012.08.007.

Gurol, C., Ekinci, F., Aslan, N., Korachi, M. (2012) Low temperature plasma for decontamination of E. coli in milk. International Journal of Food Microbiology, 157, 1-5. DOI: 10.1016/j.ijfoodmicro.2012.02.016.

Langmuir, I. (1928) Oscillations in ionized gases. Proceedings of the National Academy of Sciences of the United States of America 14, 627.

Liang, Y., Wu, Y., Sun, K., Chen, Q., Shen, F., Zhang, J., Yao, M., Zhu, T., Fang, J. (2012) Rapid inactivation of biological species in the air using atmospheric pressure nonthermal plasma. Environmental Science \& Technology, 46, 3360-3368. DOI: $10.1021 /$ es203770q

Liao, X., Liu, D., Xiang, Q., Ahn, J., Chen, S., Ye, X., Ding, T. (2017) Inactivation mechanisms of non-thermal plasma on microbes: A review. Food Control, 75, 83-91. DOl:10.1111/1541-4337.12379.

Lu, H., Patil, S., Keener, K. M., Cullen, P., Bourke, P. (2014) Bacterial inactivation by high-voltage atmospheric cold plasma: influence of process parameters and effects on cell leakage and DNA. Journal of Applied Microbiology, 116, 784-794. DOI: 10.1111/jam.12426.

Lukić, K., Vukušić, T., Tomašević, M., Ćurko, N., Gracin, L., Kovačević Ganić, K. (2019) The impact of high voltage electrical discharge plasma on the chromatic characteristics and phenolic composition of red and white wines. Innovative Food Science and Emerging Technologies, 53, 70-77. DOI: 10.1016/j.ifset.2017.11.004.

Misra, N., Patil, S., Moiseev, T., Bourke, P., Mosnier, J., Keener, K., Cullen, P. (2014) In-package atmospheric pressure cold plasma treatment of strawberries. Journal of Food Engineering, 125, 131-138. DOI: 10.1016/j.jfoodeng.2013.10.023. Misra, N., Tiwari, B., Raghavarao, K., Cullen, P. (2011) Nonthermal plasma inactivation of food-borne pathogens. Food Engineering Reviews, 3, 159-170. DOI: 10.1007/s12393-011-9041-9.

Oelofse, A., Pretorius, I., Du Toit, M. (2008) Significance of Brettanomyces and Dekkera during winemaking: a synoptic review. South African Journal for Enology and Viticulture, 29, 128-144.

Roth, J. R., Nourgostar, S., Bonds, T. A. (2007) The one atmosphere uniform glow discharge plasma (OAUGDP)A platform technology for the 21st century. IEEE T. Plasma Science and Technology, 35, 233-250. DOI: 10.1109/ TPS.2007.892711.

Scholtz, V., Pazlarova, J., Souskova, H., Khun, J., Julak, J. (2015) Nonthermal plasma-a tool for decontamination and disinfection. Biotechnology Advances, 33, 1108-1119. DOI: 10.1016/j.biotechadv.2015.01.002.

Serpaggi, V., Remize, F., Recorbet, G., Gaudot-Dumas, E., Sequeira-Le Grand, A., Alexandre, H. (2012) Characterization of the "viable but nonculturable"(VBNC) state in the wine spoilage yeast Brettanomyces. Food Microbiology, 30, 438-447. DOI: 10.1016/j.fm.2011.12.020.

Stulić, V., Vukušić, T., Butorac, A., Popović, D., Herceg, Z. (2019) Proteomic analysis of Saccharomyces cerevisiae response to plasma treatment. International Journal of Food Microbiology, 292, 171-183. DOI: 10.1016/j.ijfoodmicro.2018.12.017.

Vukušić, T., Shi, M., Herceg, Z., Rogers, S., Estifaee, P., Thagard, S. M. (2016) Liquid-phase electrical discharge plasmas with a silver electrode for inactivation of a pure culture of Escherichia coli in water. Innovative Food Science and Emerging Technologies, 38, 407-413. DOI: 10.1016/j.ifset.2016.07.007.

Prispjelo/Received: 1.9.2019.

Prihvaćeno/Accepted: 26.9.2019. 